\title{
Empire and Exile: reflections on the Ibis trilogy Clare Anderson
}

\section{Acknowledgements}

The research leading to these results has received funding from the European Research Council under the European Union's Seventh Framework Programme (FP/2007-2013) / ERC Grant Agreement 312542, and from the Economic and Social Research Council (R000271268/ RES-000-22-3484). I am grateful to both funders, as also to the article's anonymous reviewers. A podcast of Clare Anderson and Amitav Ghosh in conversation with Stephanie Jones, John McAleer, Anshuman Mondal and Harry Whitehead, during the Literary Leicester Festival 2013, can be found here: https://soundcloud.com/artshumlaw/amtiav-ghosh-on-history-and-fiction?in=artshumlaw/sets/literary-leicester2013 (accessed 14 July 2016).

[NB: The insertion of the first part of this text is a requirement of my current funder. The first part of the sentence [The research leading to these results has received funding from the European Research Council under the European Union's Seventh Framework Programme (FP/2007-2013) / ERC Grant Agreement 312542] is clunky but written by the funder and cannot be changed!!!]

The Ibis trilogy - Sea of Poppies (2008), River of Smoke (2011) and Flood of Fire (2015) - takes forward the concerns of Amitav Ghosh's fourth novel, The Glass Palace (2000), by exploring the relationship between what might be termed the global and the local in world history. That is, together the novels constitute a fictional consideration of the big processes that made the modern world, as they were co-opted, experienced, and contested in various imperial or semi-colonial contexts. The Glass Palace centers on the political and personal relationships that straddled the Bay of Bengal. Its chronology stretches from the annexation of Burma in the nineteenth century to the Second World War and its aftermath. In the Ibis trilogy, Ghosh renders more expansive still the theme of connected Empire through the literary creation of an Indian Ocean and South China Sea of subaltern lives, which moves from the early nineteenth century to the present day.

Key to the texts is the use of the narcotic drug opium as a narrative device. Across contexts, at the macro level Ghosh explores the impact of war, trade, economy, and the so-called civilization and progress of the British East India Company. At the micro level, he examines the inversions of society and culture, and the impact of Empire on people's lives. In both respects opium is always a source of degradation. It degrades the great economic machinery of the Company, which is portrayed as the world's first organized drugs smuggler (River of Smoke, 379); workers in the opium factory of Ghazipur in the north Indian province of Bihar; men like our heroine Deeti's first husband Hukam Singh who become addicts in seeking solace from the pain of injuries sustained as colonial sepoys (Sea of Poppies, 31-3); and those who fall victim to the Company's aggressive drugpeddling in Canton, such as convict Ahfat, who is prepared even to urinate on his kindly shipmate at the promise of a taste of the pipe (Sea of Poppies, 421). Opium performs additional work in the novels too. It represents the ambivalence of Empire, by serving as an ironic palliative for its violent effects. It dulls the pain of the prison tattooist's needle in Calcutta's Alipore jail (Sea of Poppies, 2689), for instance, and relaxes a condemned man before his execution in Canton (River of Smoke, 331). It also both constitutes and acts as an allegory for a connected world where land, river and sea together enable movement, even of those under punishment or labour contract; where people forge new, creolized and cosmopolitan worlds, even in the least promising of circumstances; and where the circular mobility of people links together the Americas, East India Company Asia, and the Indian Ocean. Further, whilst Rajkumar's teak trading in The Glass Palace is a useful means of representing native complicity in imperial rapaciousness, opium in the Ibis trilogy enables a further unpacking of the complexities of colonial power, including local engagement with and resistance against Empire.

The Ibis trilogy, and its literary rendering of the intersections between the global and the 
local, reveals a great deal about the tensions and experiences of Empire, and in many ways the novels present an imagined world that historians of the Indian Ocean glimpse much less completely, and only through fragments in the colonial archives. One key element in this respect is the trilogy's representation of the political, economic and social dimensions of exile, penal transportation and indentured migration. Indeed, punishment, shipment and forced labor mobility are vital elements in Ghosh's narrative reconstruction of the past. Imperial transportation and penal labor were means of imperial pacification and expansion, and the geographical scale and scope of convict transportation was wide. From the late eighteenth century, the East India Company set up penal settlements, penal colonies and spaces of exile all over British Asia and the Indian Ocean, including in Aden, the Andaman Islands, Bencoolen, Burma, Mauritius, and the Straits Settlements (Malacca, Penang and Singapore) - as also parts of subcontinental India, in the Nilgiri hills and Mahabaleshwar. Indentured migrants from India and China were sent simultaneously and subsequently to British sugar colonies in Mauritius and the Caribbean, and to railway building projects in East Africa. Some of them were routed through the French colony of Pondicherry, and destined for Réunion Island or the Antilles. There, in actions that underline Ghosh's connected history of Empire, some committed offences and joined the flow of metropolitan and colonial convicts transported to the notorious penal colony in French Guiana. However, in only a handful of cases have historians been able to trace the lives of individuals as they moved to and from imperial spaces, or to retrieve even heavily mediated representations of their experiences of crossing spaces, cultures, and societies. Writing about ordinary lives - and the intersections between different places, colonies and labor flows - becomes an exercise in subaltern prosopography, and relies on a global and creative approach to piecing together different kinds of records from multiple repositories. $^{1}$

Like the other novels in the trilogy, Sea of Poppies is firmly grounded in this historiography, and there is an important point to be made here about the larger relationship between history and fiction. As Ghosh himself put it in a recent interview, where there is only limited historical evidence of the perspectives of ordinary people: 'Fiction allows us to reach for the trace.'2 Here, Ghosh underscores the importance of understanding the political context that his characters inhabited, but argues that because events can unfold through their eyes, fiction allows 'wholeness' that is unavailable to historians. Whilst historians are more concerned, perhaps, with laying out narratives of events and understanding their place in larger historical processes, novelists can address questions of emotion and affect. In this sense, as Ghosh put it in a further discussion, his responsibility is to the men and women that lie at the heart of his fiction. 'For me, seeing the past through the prism of a character allows me understand some aspects of the past that historians don't deal with,' he said. 'But ... doing this would not be possible if historians had not laid the foundations." ${ }^{3}$ His perspective is vital for understanding both how the novelist's work is different to that of the historian, and also for appreciating the value of fiction to the construction of history from below. At the heart of the difference between novelists and historians lie questions of method, and whilst it is the storyteller and not the historian who is most able to write about ordinary people

\footnotetext{
${ }^{1}$ Clare Anderson, "Sepoys, Servants and Settlers: Convict Transportation in the Indian Ocean, 1787-1945," in Ian Brown and Frank Dikötter, eds, Cultures of Confinement: A History of the Prison in Africa, Asia and Latin America (Ithaca, 2007), 185-220; Clare Anderson, Subaltern Lives: biographies of colonialism in the Indian Ocean world, 1790-1900 (Cambridge, 2012); Clare Anderson, Madhumita Mazumdar and Vishvajit Pandya, New Histories of the Andaman Islands: landscape, place and identity in the Bay of Bengal, 1790-2012 (Cambridge, 2016); Clare Anderson, 'A Global History of Exile in Asia, c. 1700-1900', in Ronit Ricci, ed., Exile in Colonial Asia: Kings, Convicts, Commemoration (Honolulu, 2016), 20-47.

2 Elleke Boehmer and Anshuman A. Mondal, "Networks and Traces," Wasafiri 27 no. 2 (2012): 30-35, here 31.

3 Mahmood Kooria, 'Between the Walls of Archives and Horizons of Imagination: An Interview with Amitav Ghosh,' Itinerario 36 no. 3 (2012): 7-18, here, 9.
} 
in the past, in the context of recent challenges to the structure and form of the (colonial) archives the line between history and fiction is perhaps more blurred than it once was. ${ }^{4}$

There is no question that the novelist is able to imaginatively reproduce worlds in ways that on the basis of the archives alone historians cannot. To take one example: Ghosh's creation of the powerful scene when disgraced rajah Neel Rattan Haldar first enters Alipore jail, and is stripped naked, inspected, and tattooed on the forehead with a mark of godna.

$<$ FIG. 1 NEAR HERE>

F.S. Marryat, Borneo and the Indian Archipelago, With Drawings of Costume and Scenery (London, 1848), 215.

Historians know that until the middle of the nineteenth century Indian convicts were tattooed prior to transportation, for the marks were noted in prison registers. Indeed, across the Indian presidencies, jail clerks made detailed descriptions of each convict's name, place of origin, crime, religion and caste, as well as skin and hair color, and bodily marks. Such records can be used in a range of ways, including interpreting transportation as a penal response to peasant resistance in parts of north India, measuring the prevalence of smallpox, and appreciating regional variations in the form of godna marks. ${ }^{5}$ But it is the novelist who can add texture to the humiliation necessarily invoked in the literal laying bare of convict bodies before a colonial state desirous of both inscribing words on them, and writing down words of them. Ghosh writes of Neel: "it was as if he had vacated his own flesh in the process of yielding it to the tenancy of the prison." (Sea of Poppies, 268.) Ghosh's creative use of the historiography in this and other parts of the trilogy has underpinned the production of a remarkable public history of a little known element of imperial history: Britain's use of convict transportation in and across Asia and the Indian Ocean as a means of degradation, exile and resource extraction. The absence of penal settlements and colonies and forced convict labor from both academic and public histories of the British Empire in the region is striking, and this renders all the more important the effects of Ghosh's previously stated commitment to the power of fiction in enabling the recreation of unfamiliar worlds and times. ${ }^{6}$ To be sure, if opium works as a vital literary allegory, exile and penal transportation underpin the spatiality of the novels. Ghosh's fictionalization of both political exile and the movement of convicts from all social classes multi-directionally around the British Empire in Asia enables a remarkably effective exploration of some of the lived experiences of colonial expansion that it is difficult for historians to access.

It is intriguing to learn that a journalist once confronted Ghosh, claiming that Sea of Poppies was a sympathetic portrayal of Empire. ${ }^{7}$ It may be that s/he was beguiled by the lyricism of Ghosh's language, which in that novel includes the 'motley tongue' of lascar shipboard pidgin (102), and later in River of Smoke, snippets of Canton English, and Mauritian Kreol: “Bon-dyé! ... Don't be ridikil ... it was nothing but ... tus in dezord ..." (15). ${ }^{8}$ Language urges us to appreciate the cosmopolitanism of the Indian Ocean, and to think of its geographical and cultural integration, and a world in which people moved seamlessly across and between mainland India, Burma, Singapore and China, and further still to Mauritius. With regard to the latter, in the novels Bhojpuri is recognized as a constituent element of Mauritian Kreol, while the languages spoken in the Chinese

\footnotetext{
${ }^{4}$ See also Antoinette Burton, “Amitav Ghosh's World Histories from Below,” History of the Present 2, no. 1 (2012): 7177.

${ }^{5}$ Clare Anderson, Legible Bodies: race, criminality and colonialism in South Asia (Oxford, 2004).

6 Damien Stankiewicz, "Anthropology and Fiction: An Interview with Amitav Ghosh," Cultural Anthropology 27, no. 3

(2012): 535-541, here 538.

7 Boehmer and Mondal, "Networks and Traces," 35.

${ }^{8}$ Bon-dyé = Good lord; ridikil = ridiculous; tus in dezord = everything is in a mess.
} 
treaty port of Canton reveal that it possessed a remarkably South Asian character. Yet the lilt of the text, and the novels' oft-times tongue-twisting and lyrical dialogue, renders all the more effective Ghosh's vehement critique of the exploitation and ruthlessness of Empire. This is not abstracted history, but an exploration of its devastating effects as it impacted on individuals and communities. To be sure, some Indians became rich, but their success is rendered ambivalent as it is set against histories of imperial loss: of health, family and home. In this respect, it is notable that across the trilogy there is an outward-facing dimension to native fortune seeking, and in the context of abject poverty or much shrunken options in home places livelihoods are sought elsewhere in the everenlarging spheres of British influence. In earlier novels this included the Burmese forests (The Glass Palace), and in the trilogy itself the opium factories of Bihar and the sugar plantations of Mauritius (Sea of Poppies), and the European enclaves and trading posts of treaty port China (River of Smoke, Flood of Fire). And yet ever-expanding Empire was at the same time made possible by the transportation, exile and containment of political opponents including subaltern rebels, as well as the mass mobility of confined forms of labor.

Ghosh further explores the intersections of place, people and Empire through the creation of a connected history of convictism, indenture and enslavement. Indeed, the Ibis, the ship that carries convicts and indentured laborers from Calcutta to Mauritius, is a former slave ship. "Have you not heard that when God closes one door he opens another? When the doors of freedom were closed to the African, the Lord opened them to ... the Asiatick. ... A hold that was designed to carry slaves will serve just as well to carry coolies and convicts,"' says Mr Burnham. "'Do you not think?"' (Sea of Poppies, 74). Literary critics have interpreted this association as a means of connecting not just modes of labor exploitation, but also the Indian Ocean to the Atlantic world. Here the figure of African American Zachary Reid is critical, for he goes to sea on the Ibis at Baltimore, seeking to escape the strictures of race, but finds in the social and cultural hierarchies of the Indian Ocean an alternative form of confinement. ${ }^{9}$ It is possible to push the analogies further than literary critics have done so far. It is clear that in the nineteenth century both officials and potential migrants viewed indenture through the prism of what they understood of the fate of convicts in penal settlements, rather than through knowledge of the Atlantic slave triangle, as has been supposed. ${ }^{10}$ Indeed, in recognizing the coeval existence of penal transportation and indentured migration, the significance of the theme of forced, coerced or semi-coerced displacement in Ghosh's writing is such that it reveals a literary commitment to the narration of imperial violence, as well as to the presentation of migration and mobility as strategies that were (and remain) available to ordinary people as a means of participating in (or resisting incorporation into) the global economy, and coping with profound economic, social and cultural change.

Ghosh deepens the affective meaning of these links by writing of the power of the journey in drawing men of diverse religions, castes and backgrounds together in brotherhood, as jahajbhais [shipmates] (Sea of Poppies, 290). He thus draws on what historians know of nineteenth-century convict and migrant perspective in rendering political and cultural inversions socially productive, too. The Ibis itself is a means through which diverse peoples can meet, and identities can be remade. ${ }^{11}$ But whilst this was a world marked by violence and exploitation, forced mobility gave rise to remarkable kinds of cultural creation. Ghosh gives voice to these through reference to a series of social and political inversions. The new cultural worlds created by penal transportation began in mainland holding jails and were consolidated on the voyage to the colonies. Sea of Poppies contains a lengthy description of Calcutta's Alipore jail, from where Bengal Presidency convicts were

\footnotetext{
${ }^{9}$ Anupama Arora, “'The Sea is History': Opium, Colonialism, and Migration in Amitav Ghosh's Sea of Poppies," ariel: a review of international english literature 42 nos. 3-4 (2012): 21-42, here 24, 34.

${ }_{10}$ Clare Anderson, "Convicts and Coolies: Rethinking Indentured Labour in the Nineteenth Century," Slavery and Abolition 30, no. 1 (2009): 93-109.

${ }^{11}$ Boehmer and Mondal, "Networks and Traces," 32.
} 
transported from the late eighteenth century onwards. The prison was what Ghosh describes as 'an archipelago of fiefdoms, each with its own rules, rulers and ruled.' (288). Alipore is a space were social norms were turned upside down, where prisoners could become jemadars (overseers) of other men, and households created anew (289). Social inversions of other kinds are scattered across the trilogy too, with race, class and gender intersecting in unusual ways. For instance, a black, low-caste man (Kalua) saves the pale-skinned near-sati Deeti from the funeral pyre (Sea of Poppies, 162-3). ${ }^{12}$ One of the other key characters, Neel Rattan Halder, is a former rajah, set up by the wealthy Benjamin Burnham on a charge of forgery, dispossessed of his lands and property, and sentenced to transportation. Mr Burnham himself is revealed a former convict, from a questionable background (Sea of Poppies, 69-71, 217-22). Later on in the story, the American sailor Zachary Reid, son of a freewoman and a black carpenter, has a passionate affair with Mr Burnham's European wife (Flood of Fire). Ghosh also stages a remarkable literary challenge to the idea of the British Empire as a civilizing force, and so turns on its head commonly accepted representations of it. Imperial commissioner Lin Zexu challenges the foreign merchants of Canton thus: 'How does it happen ... that you bring opium to our central land ... with this thing you have seduced and deluded the people of China ... countless are the unjust hoards that you have thus accumulated ...' Ghosh notes the 'incredulous murmurs' of the Canton traders as the commissioner's words are read out loud, and their apparent defense of their position through an invocation of the Chinese punishments of the cangue and execution by strangling (River of Smoke, 402, 403).

Perhaps the most powerful evocation of the relationship between these worlds turned upside down, these connections, and their cultural and affective productivity, is the moment when the fallen rajah, high-caste transportation convict Neel, enters the precincts of Alipore and the jail overseer [jemadar] introduces him to his new cellmate, half-Parsi half-Chinese opium addict Ahfat:

Neel became aware of a whimpering sound ... he dropped to his knees ... to discover an unmoving heap ... the man was covered in ... faeces and vomit ... Neel clutched the bars of the cell, calling out ... You can't leave me here, have pity ... [The jemadar] turned around ... Listen, he said ... if you think you can hide from this man you are wrong. From now on, you will never be able to escape this Aafat. He will be on your ship and you will have to travel with him to your jail across the Black Water. He is all you have, your caste, your family, your friend; neither brother nor wife nor son will ever be as close to you as he will. You will have to make of him what you can; he is your fate, your destiny. Look in a mirror and you will know: you cannot escape what is written on your forehead. (Sea of Poppies, 291).

This first meeting sets the scene for a series of remarkable encounters across the trilogy, in which the spaces-in-between are in many ways more important than the land. As Ghosh puts it, ships' crews "had nothing in common except the Indian Ocean." (Sea of Poppies, 22.) And yet it is the juxtaposition of the related unfreedoms of the enslaved, convicted and indentured, and of color, caste and gender, that makes a key intervention in the representation of the political economy of the East India Company. Violence and exploitation spread from the lands of opium production, downriver and over sea. Seafaring and indenture emerged as a means of absorbing those disposed of their lands, and penal transportation a mode of governmentality, perpetuating further imperial expansion. Ghosh writes of a world of entangled history, of violence, power and resistance. His work is not abstracted 'history,' but contains rich meanings of the effects of Empire on people's lives. The trilogy is engaged with the spirit of historical recovery so central to the Subaltern Studies project, but infused with more nuanced, post-nationalist global history concerns.

${ }^{12}$ Arora describes this as "writing back" against colonial and British fictional representations: “'The Sea is History,'” 26. 